\section{Fragrance Analysis of Two Scented Hippeastrum Species}

\author{
Alan W. Meerow ${ }^{1}$, Stewart T. Reed, Christopher Dunn, \\ and Elena Schnell \\ U.S. Department of Agriculture, Agricultural Research Service, Subtropical \\ Horticulture Research Station, 13601 Old Cutler Road, Miami, FL 33158
}

Additional index words. volatile organic compounds, fragrant flowers, Amaryllidaceae, Hippeastrum genetics and breeding, pollination ecology, gas chromatography, mass spectrometry

\begin{abstract}
We report the analysis of floral fragrance volatiles from two scented amaryllis species, Hippeastrum brasilianum and Hippeastrum parodii. Whereas the headspace of $\boldsymbol{H}$. brasilianum is dominated by a large peak of $(Z)-\beta$-ocimene $(88 \%$ of total peak area), $H$. parodii has two large peaks comprising $78 \%$, identified as eucalyptol $(1,8$-cineole, $30 \%)$ and $(Z)-\beta$-ocimene $(\mathbf{4 8} \%)$. The two species also differ in other constituent compounds. Overall, $\boldsymbol{H}$. parodii, although producing less total volatile organic compounds (VOCs), has a more diverse bouquet. This species also exhibits an inverse pattern of emission between eucalyptol and $\beta$-ocimene, both daily and across the 4-day period from anthesis to senescence of the flower. We compare our results with reports for a complex amaryllis hybrid and a bat-pollinated species, Hippeastrum calyptratum. The hybrid had a very different complement of emissions. The bat-pollinated species shared some of the same constituent volatiles as $H$. brasilianum and $H$. parodii, but at lower percentages, and emitted a more diverse assortment of compounds. We conclude that both $H$. brasilianum and $H$. parodii attract lepidopteran pollinators but suggest that $\boldsymbol{H}$. parodii may also attract other insects. We briefly discuss floral fragrance from the perspective of breeding amaryllis.
\end{abstract}

After color, fragrance is the second most important phenotypic character in consumer choice of floral products (Chandler and Brugliera, 2011). Flower fragrance is a complex character involving a combination of molecules synthesized endogenously by plants. Floral odors generally are a blend of several chemical substances that fall into three categories: terpenoids, phenylpropanoids/benzenoids, and fatty acid derivatives (Dudareva and Negre, 2005; Knudsen et al., 1993). Although the pathways leading to the final products have not been completely characterized, common modifications such as hydroxylation, acetylation, and methylation have been described (Amrad et al., 2016; Dudareva and Pichersky, 2000, 2006; Ramya et al., 2017).

As yet, there is no single model system for the elucidation of the genetics of floral fragrance synthesis or expression in plants (Guterman et al., 2002), although much progress has been made (Dudareva et al., 2013). Floral fragrance is not a character that can be observed visually and is rarely consistent biochemically (and thus, by inference, genetically as well). The flowers of Arabidopsis, a model for so many plant genetic pathways, do not produce many VOCs (Vainstein et al., 2001). Consequently, genetic characterization of flower scent is still incomplete (Dudareva and Negre, 2005; Dudareva and Pichersky, 2000, 2006). A few floral fragrance genes have

Received for publication 7 Sept. 2017. Accepted for publication 24 Oct. 2017.

${ }^{1}$ Corresponding author. E-mail: alan.meerow@ars. usda.gov. been identified from plants with very fragrant flowers (e.g., Clarkia breweri and Antirrhinum majus; Dudareva et al., 1996; Vainstein et al., 2001). Verdonk et al. (2005) isolated a transcription factor that regulates floral scent biosynthesis in Petunia, and the large MYB transcription factor family has been implicated in fragrance emission regulation in other plants as well (Ramya et al., 2017).

Flowers often contain a mixture of VOCs that combine to make a characteristic scent. For example, the four o'clock flower (Mirabilis jalapa L.) scent contained as its major component the terpenes $(E)$ - $\beta$-ocimene with detectable amounts of $\beta$-myrcene, $(Z)-\beta$-ocimene, $(E)$-epoxy-ocimene, an aliphatic $(Z)$-3-hexenyl acetate, and a benzenoid benzyl benzoate (Effmert et al., 2005). Minor components included alloocimene, ( $Z$ )-3-hexenol, and methyl salicylate (Effmert et al., 2005). Pink snapdragon (A. majus L.; Dudareva et al., 2000), an orchid (Calanthe sylvatica Lindl.; Delle-Vedove et al., 2011), Silene L. spp. (Jurgens et al., 2002), tree peony (Paeonia suffruticosa Andrews; Li et al., 2012), Hieracium L. subgen. Piloselloidea (W.D.J. Koch) Peterm. (Feulner et al., 2009), the Peruvian lily (Alstroemeria L. hybrids; Aros et al., 2012), and Dianthus inoxianus Gallego (Balao et al., 2011) are examples of plants that emit some mixture of terpenoids, phenylpropanoids, benzenoids, or fatty acid derivatives as major components of floral scent.

Plants emit floral scents not only to attract pollinators but also to attract predators of insect herbivores or as repellents against herbivores (Dudareva and Negre, 2005; Gershenzon et al., 2000; Pare and Tumlinson, 1997). Different insects exhibit a wide range of daily activity patterns (Herrera, 1990). In turn, many plants emit floral volatile compound in a rhythmic pattern (Fenske and Imaizumi, 2016). The bouquet of fragrant volatile compounds emitted may change over time and at different locations within an inflorescence. For example, Hosta plantaginea Asch. and Protea L. spp. emit a different combination of volatile chemicals as the flower ages (Liu et al., 2014; Steenhuisen et al., 2010). Day or night variation in scent components has been documented for several species. Dianthus inoxianus, snapdragon, Odontoglossum constrictum Lindl., Citrus medica L., Hoya carnosa R. Br., Stephanotis floribunda Brongn., and Nicotiana L. spp. all exhibit nocturnal or diurnal volatile emission pattern variations (Altenburger and Matile, 1988; Balao et al., 2011; Kolosova et al., 2001; Loughrin et al., 1990; Matile and Altenburger, 1988; Raguso et al., 2003).

Hippeastrum Herb. consists of $60-70$ species distributed exclusively in tropical and subtropical America (Meerow, 2009). Most of the species do not produce noticeable floral fragrance, which is hypothesized to be a recessive trait in the genus (Meerow, 2009). Hummingbirds have been the most frequently observed flower visitors in Hippeastrum (Araujo and Sazima, 2003; Freitas and Sazima, 2006; Sazima et al., 1996). Fragrance has been observed notably in white (rarely yellow), long-tubed species such as Hippeastrum brasilianum (Traub and J.L. Doran) Dutilh, Hippeastrum elegans (Spreng.) H.E.Moore, Hippeastrum fragrantissimum, and Hippeastrum parodii Hunz. and Cocucci. Several pink-flowered, long-tubed species also produce fragrance (e.g., Hippeastrum doraniae (Traub) Meerow). The bat-pollinated (Vogel, 1969) epiphytic species Hippeastrum calyptratum (Ker Gawl.) Herb., has a very different floral odor, described variously as stale, sour, or fermented (Bestmann et al., 1997) and to date is the only species of the genus to have floral fragrance analyzed (Bestmann et al., 1997). Liu and Yeh (2015) reported fragrance volatiles for Hippeastrum 'Blossom Peacock' and its progeny 'T.S.S. No.1-Pink Pearl', a double-flowered complex hybrid (H. 'San Remo' $\times$ 'Blossom Peacock').

Fragrance has not been a major target of amaryllis breeders who traditionally select for color characteristics (Meerow, 2009). Introducing fragrance into nonscented varieties has the potential to increase demand for amaryllis plants and add to their value as cut flowers as well. The goals of this study were to determine the range of volatile compounds in two Hippeastrum species that produce fragrance, to study temporal patterns in scent emission, attempt to infer likely pollinators, and potentially help identify candidate genes for fragrance expression in the future from Hippeastrum transcriptome data.

\section{Materials and Methods}

Floral volatile compounds were analyzed from two fragrant species, $H$. brasilianum, 
a Brazilian planalto species from Minas Gerais and Espirito Santo states and $H$. parodii, a tropical desert species native to southwestern Bolivia and northwestern Argentina.

Volatile collection and analysis. Plants were grown in the United States Department of Agriculture/Agricultural Research Service greenhouse, Miami, FL (lat. $25^{\circ} 38.577815^{\prime} \mathrm{N}$, long. $80^{\circ} 17.545062^{\prime} \mathrm{W}$ ) and were transferred into the laboratory for volatile collection. Flowers, fully open for $24-48 \mathrm{~h}$ were enclosed in commercially available oven bags, loosely sealed with a twist tie, and kept at ambient temperature for $1 \mathrm{~min}$ before sampling. Volatile chemicals were sampled by solid-phase microextraction (SPME) with a $100-\mu$ m polydimethyl siloxane coating (nonbonded) fiber (Supelco, Bellefonte, PA). Fibers were inserted through a small hole in the oven bag and exposed to headspace volatiles for $1 \mathrm{~min}$. Hippeastrum brasilianum and Hippeastrum parodii flower's volatile samples were taken once every hour for 24 straight hours and repeated twice with different flowers from the same inflorescence. In addition, $H$. parodii flower volatiles were sampled daily at 10:00 AM from anthesis until senescence.

All chemical samples were analyzed using an Agilent 5975B gas chromatography (GC)-mass spectrometer (Agilent Technologies, Santa Clara, CA) in the electron impact mode. The column used was a DB5-MS $25 \mathrm{~m}$ $\times 0.25 \mathrm{~mm} \times 0.25 \mu \mathrm{m}$ column (J\&W Scientific/ Agilent Technologies, Santa Ana, CA) and helium was used as a carrier gas at 1.2 $\mathrm{mL} \cdot \mathrm{min}^{-1}$. The oven temperatures were programmed to increase from $45{ }^{\circ} \mathrm{C}$ to
$130{ }^{\circ} \mathrm{C}$ at $10.0{ }^{\circ} \mathrm{C} \mathrm{min}-1$, then from 130 to $220{ }^{\circ} \mathrm{C}$ at $15.0^{\circ} \mathrm{C} \cdot \mathrm{min}^{-1}$, and then kept at $220{ }^{\circ} \mathrm{C}$ for $2 \mathrm{~min}$. Before each set of samples was collected, the SPME fiber was conditioned for $2 \mathrm{~min}$ at $220^{\circ} \mathrm{C}$ in the GC-mass spectrometer injection port, and a fiber blank was recorded before initial sampling. $\mathrm{A}_{6}$ to $\mathrm{C}_{16}$ alkane standard was analyzed for retention time reference data for Kovats indices calculations. Volatile chemicals were identified based on the comparison of mass spectra with the National Institute of Standards and Technology (NIST) Mass Spectral Program version 2.0d and NIST/EPA/NIH Mass Spectral Library (NIST11). Further confirmation was achieved by comparing the putative chemicals' mass spectra and Kovats indices with commercial standards (Sigma Aldrich, Milwaukee, WI) tested using the same GC-mass spectrometer and method used for flower volatile analysis. Where standards were not available, unknowns were tentatively identified by the best match from the NIST libraries. Minor peaks appearing in only one sample of the same species were ignored. A putative match for most major volatile compounds was found with a reverse match of 852 or higher.

\section{Results}

Peak identification. Five major volatile peaks were detected from $H$. brasilianum (Table 1; Fig. 1A). Among these, $\beta$-ocimene (including both cis and the much lower percentage trans stereoisomers) was the dominant constituent, occurring at all 24 sampling times in the highest amounts (Fig. 2A). Linalool, methyl salicylate, and methyl benzoate occurred in most of the samples and each made up at least $1 \%$ of the total volatile content (Fig. 2B).

Seven volatile peaks were identified in $H$. parodii emissions over a $24-\mathrm{h}$ period (Table 1 ; Figs. $1 \mathrm{~B}$ and $3 \mathrm{~A}$ ). (Z)- $\beta$-Ocimene $(49 \%)$, eucalyptol $(30 \%)$, and myroxide $(10 \%)$ were found in largest amounts. In addition to compounds named previously, nonanal, decanal, and a compound provisionally identified as 2,6-bis(1,1-dimethylethyl)4-(1-oxopropyl)phenol appeared in the bouquet of volatile compounds consistently throughout the 24-h sampling period (Fig. 3B). Caryophyllene, comprising just more than $1 \%$ of total emissions, occurred in only 12 counts.

Temporal variation. The sum of all $H$. brasilianum volatile emissions were greater during daylight hours $\left(2.9 \times 10^{6}\right.$ counts $)$ than after sunset $\left(1.4 \times 10^{6}\right.$ counts) (Fig. 4A). Linalool appeared throughout the 24-h sampling time span but was the only volatile that had its highest peaks during daylight hours (Fig. 2B). For H. parodii, a summation of all peak areas for each hour (Fig. 4B) revealed that there were greater total volatile emissions after sunset $\left(2.1 \times 10^{6}\right.$ counts $)$ than during daylight $\left(1.5 \times 10^{6}\right.$ counts $)$ hours (4 June 2015 sunrise 6:29 AM; sunset, 8:09 PM).

Total scent emissions in $H$. brasilianum came in pulses. During daylight hours, there was roughly $2 \mathrm{~h}$ between peak outputs (Fig. 4A). After sundown, frequency of the higher pulses' recurrence slowed. Evening pulses had higher peaks and lower troughs than the relatively steadier output during the day. Volatile emissions were slightly higher between 11:00 AM and 4:00 PM than they were

Table 1. Major volatile compounds, as a percent of total emissions over a 24-h period, from Hippeastrum brasilianum, and Hippeastrum parodii, mean of two analyses $( \pm \mathrm{SD})$.

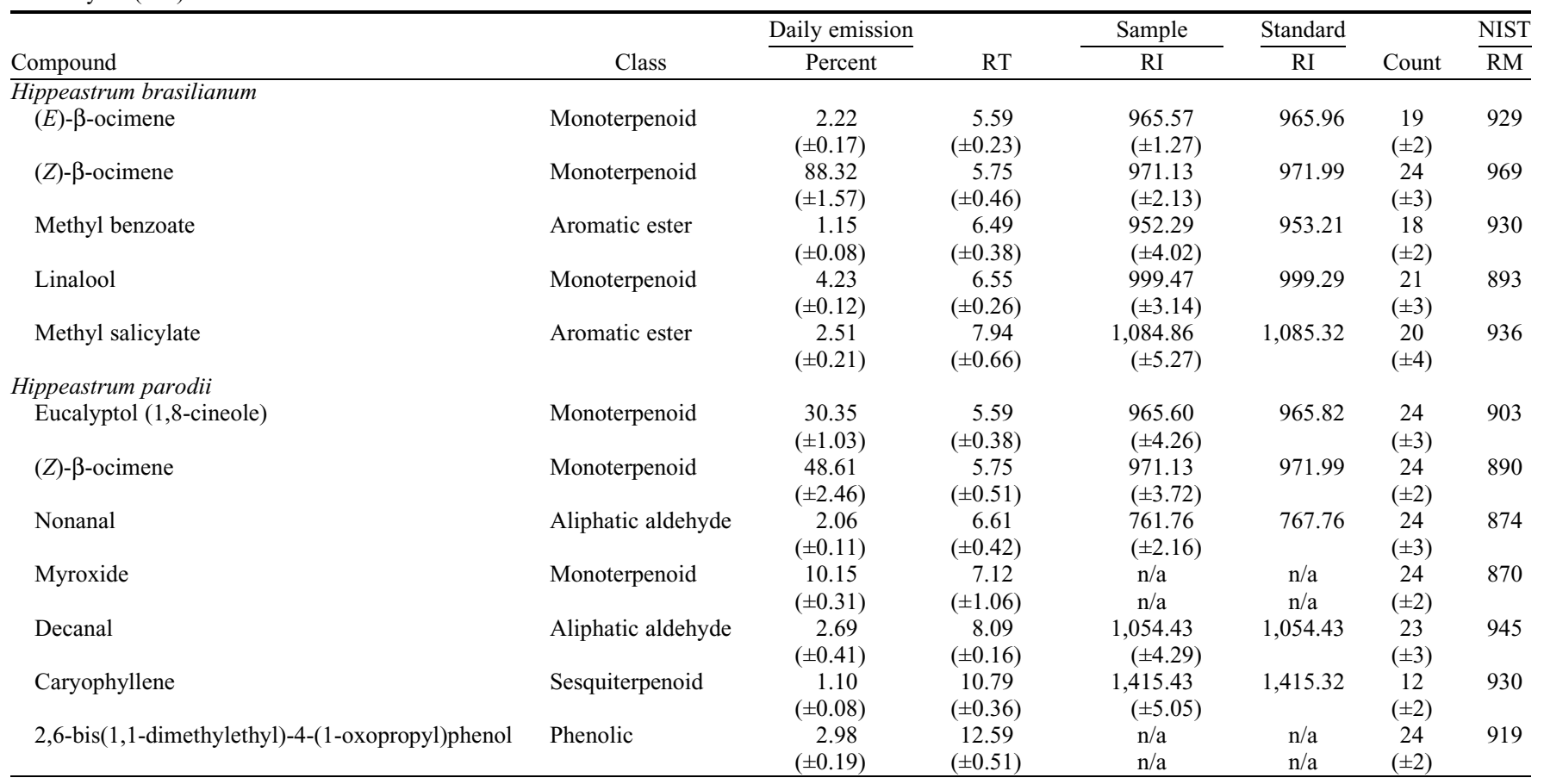

NIST = National Institute of Standards and Technology; RT = retention time; RI = Kovats Retention Index; RM = reverse match; and count = the number of occurrence in hourly samples over a $24 \mathrm{~h}$ period. Identification by comparison (mass spectrum electron ionization) to a commercial standard and RI. $\mathrm{n} / \mathrm{a}=\mathrm{no}$ standard available. 


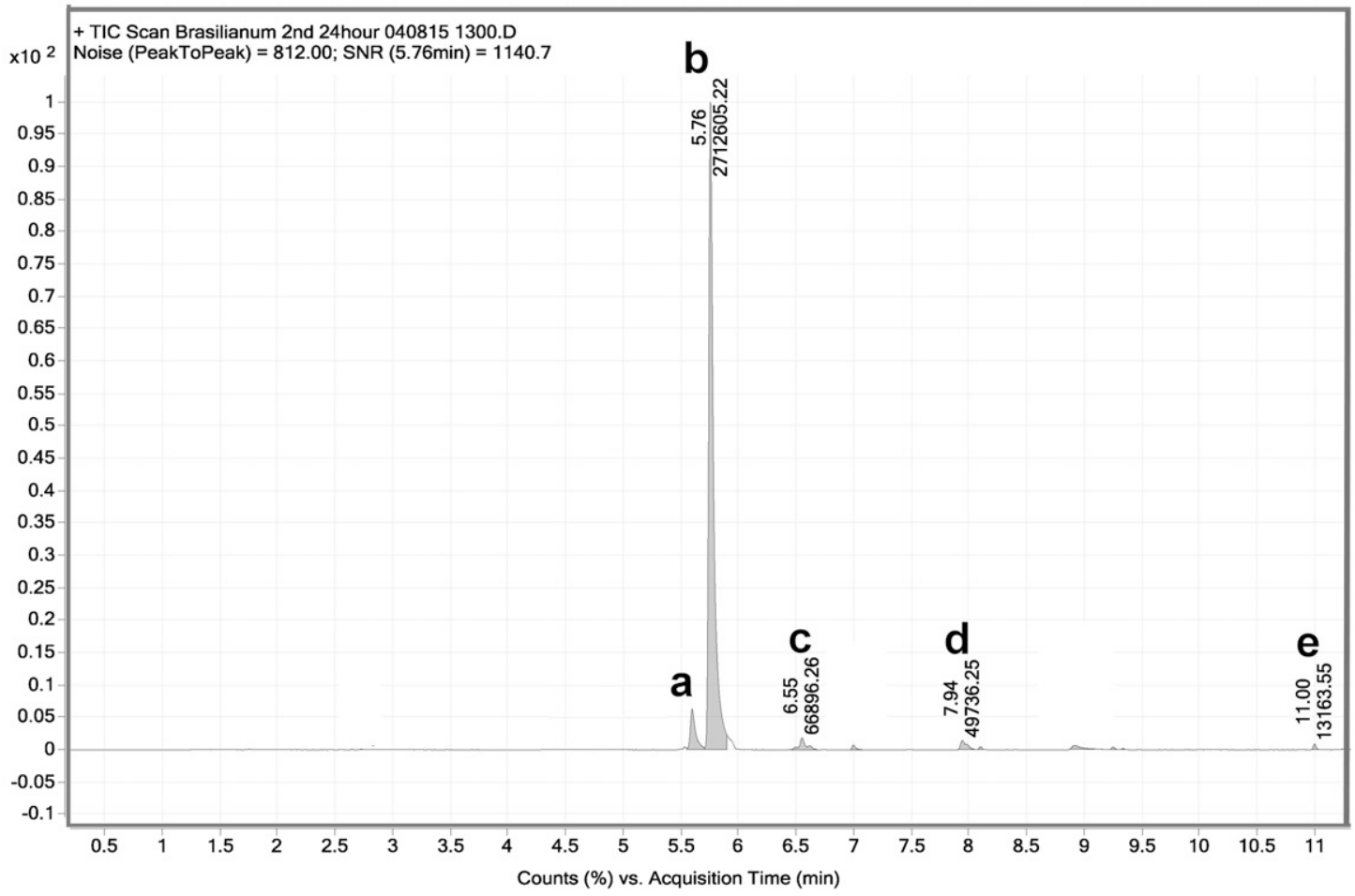

B

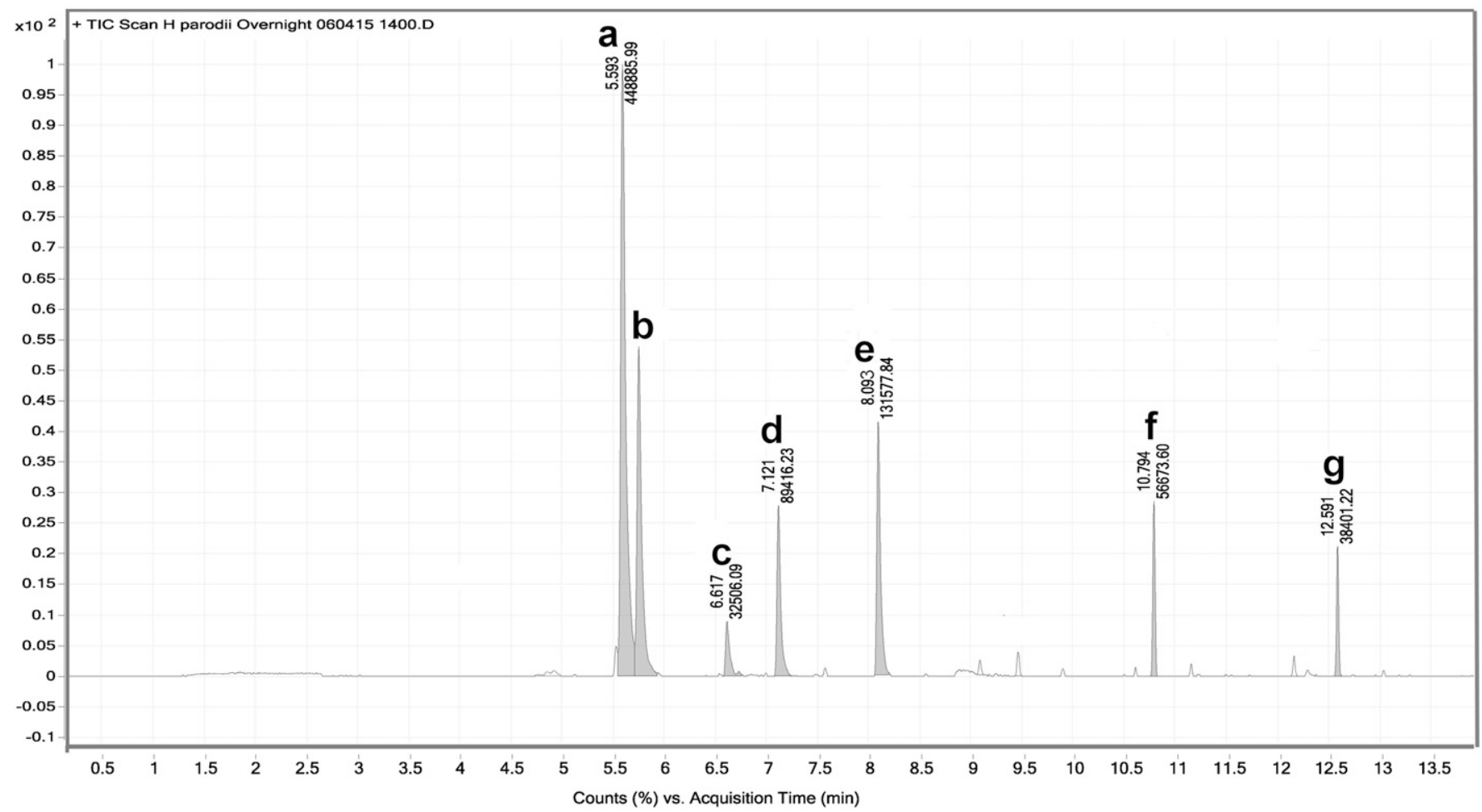

Fig. 1. Representative gas chromatography-mass spectrometer chromatograms of percent counts vs. acquisition time containing the most frequently reoccurring peaks for volatile compounds found in two fragrant Hippeastrum spp. (A) Hippeastrum brasilianum, 1:00 PM, 8 Apr. 2015. (a) (E)- $\beta$-ocimene, (b) (Z)- $\beta$-ocimene, (c) methyl benzoate, (d) linalool, (e) methyl salicylate. (B) Hippeastrum parodii, 2:00 PM, 4 June 2015. (a) Eucalyptol, (b) (Z)- $\beta$-ocimene, (c) nonanal, (d) myroxide, (e) decanal, (f) caryophyllene, (g) 2,6-bis(1,1-dimethylethyl)-4-(1-oxopropyl)phenol.

for the rest of the afternoon and throughout the night. At dawn, peak emission began to increase but with continued large differences between high and low point in the pulse.
The major volatiles of $H$. parodii, eucalyptol and (Z)- $\beta$-ocimene, had opposite emission patterns throughout the day (Fig. 3A). As relative counts for eucalyptol increased from
8:00 AM until 11:00 AM, those for ( $Z$ )- $\beta$-ocimene decreased. Eucalyptol emissions were higher beginning a little after 9:00 AM until after 4:00 PM when $(Z)$ - $\beta$-ocimene became the dominant 


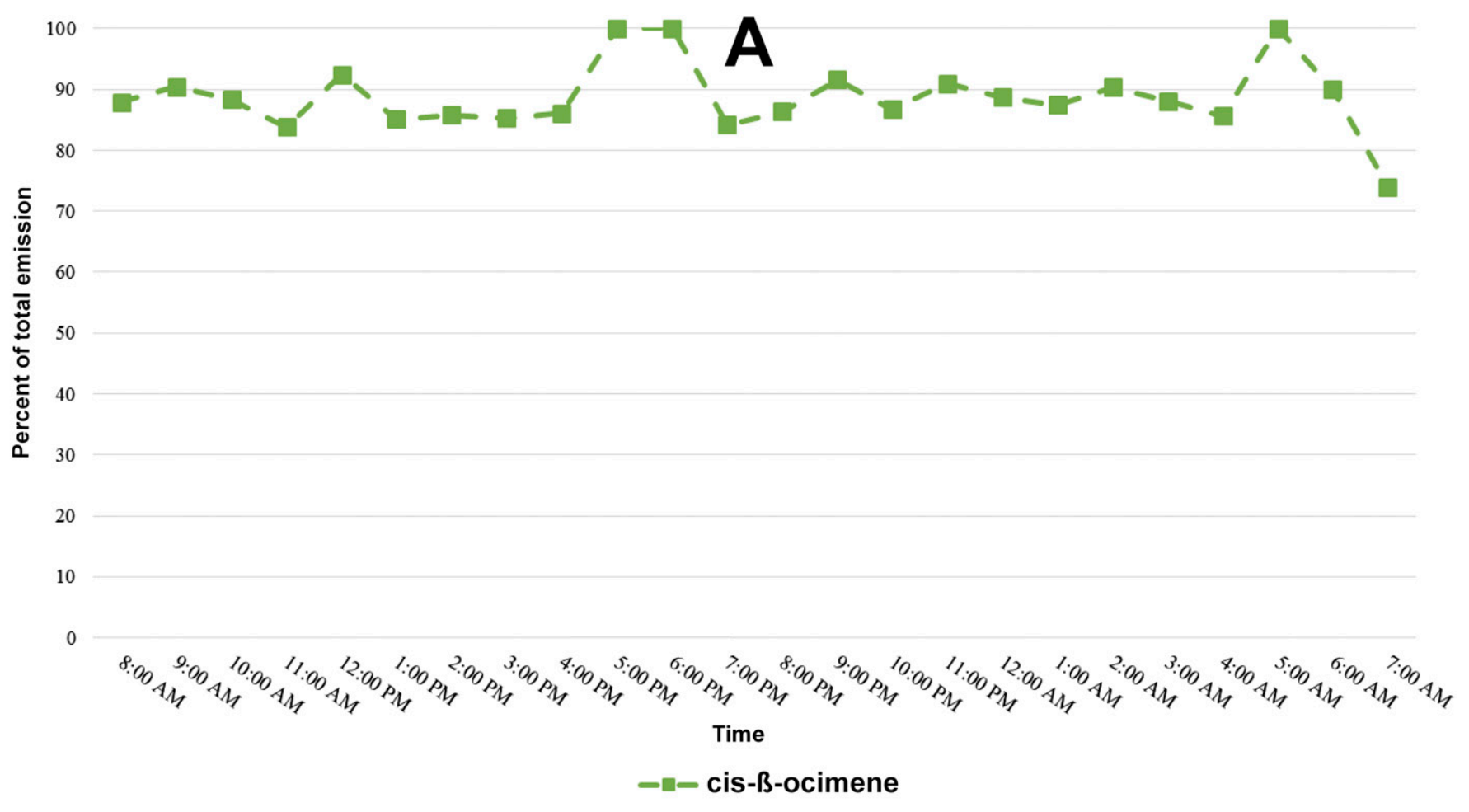

16

14

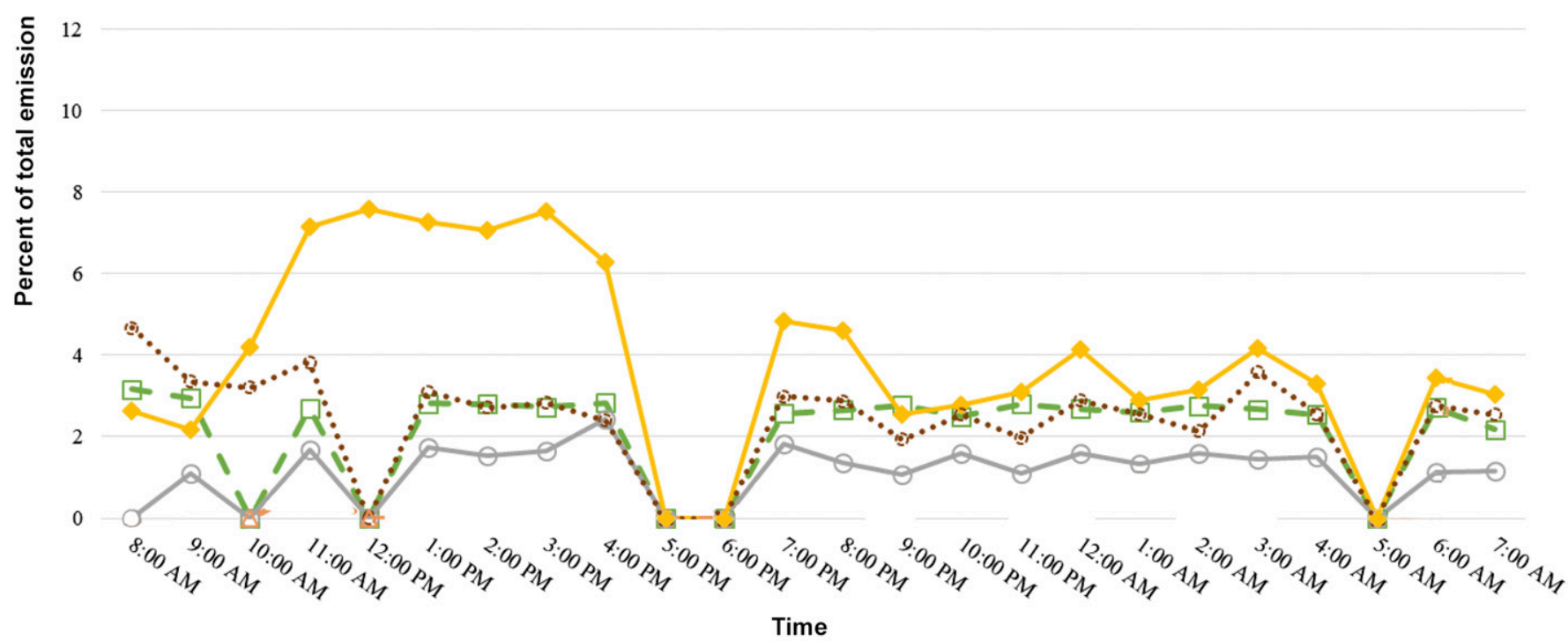

$\multimap \square-$ trans-ß-ocimene $\multimap$ methyl benzoate $\multimap$ linalool... methyl salicylate

Fig. 2. Occurrence of volatile compounds emitted from Hippeastrum brasilianum flowers over a 24-h period. (A) Major volatile compounds. (B) Minor volatile compounds.

fragrant compound. Among the minor volatiles, caryophyllene emissions began in the early morning and ceased shortly after sunset (4 June 2015 sunrise 6:29 AM; sunset, 8:09 PM). Decanal emissions were continuous throughout the day; however, they were notably higher from 8:00 AM through 4:00 PM with peak emission at 2:00 PM. In H. parodii, the only species for which volatiles were collected from anthesis until senescence of the flower, six volatile compounds [eucalyptol, $(Z)$ - $\beta$-ocimene, nonanal, decanal, myroxide, and 2,6-bis(1,1-dimethylethyl)-4-(1oxopropyl)phenol] were emitted on all $4 \mathrm{~d}$ before the flower wilted (not shown). These six compounds accounted for $51 \%$ to $85 \%$ of total emissions each day. (Z)- $\beta$-Ocimene and eucalyptol, the two dominant components of $H$. parodii fragrance, had opposite emission patterns over the time span between flower opening and wilting. As the percentage of ocimene emitted increased, that of eucalyptol decreased; after day 2, this pattern reversed and ocimene decreased in favor of eucalyptol. 

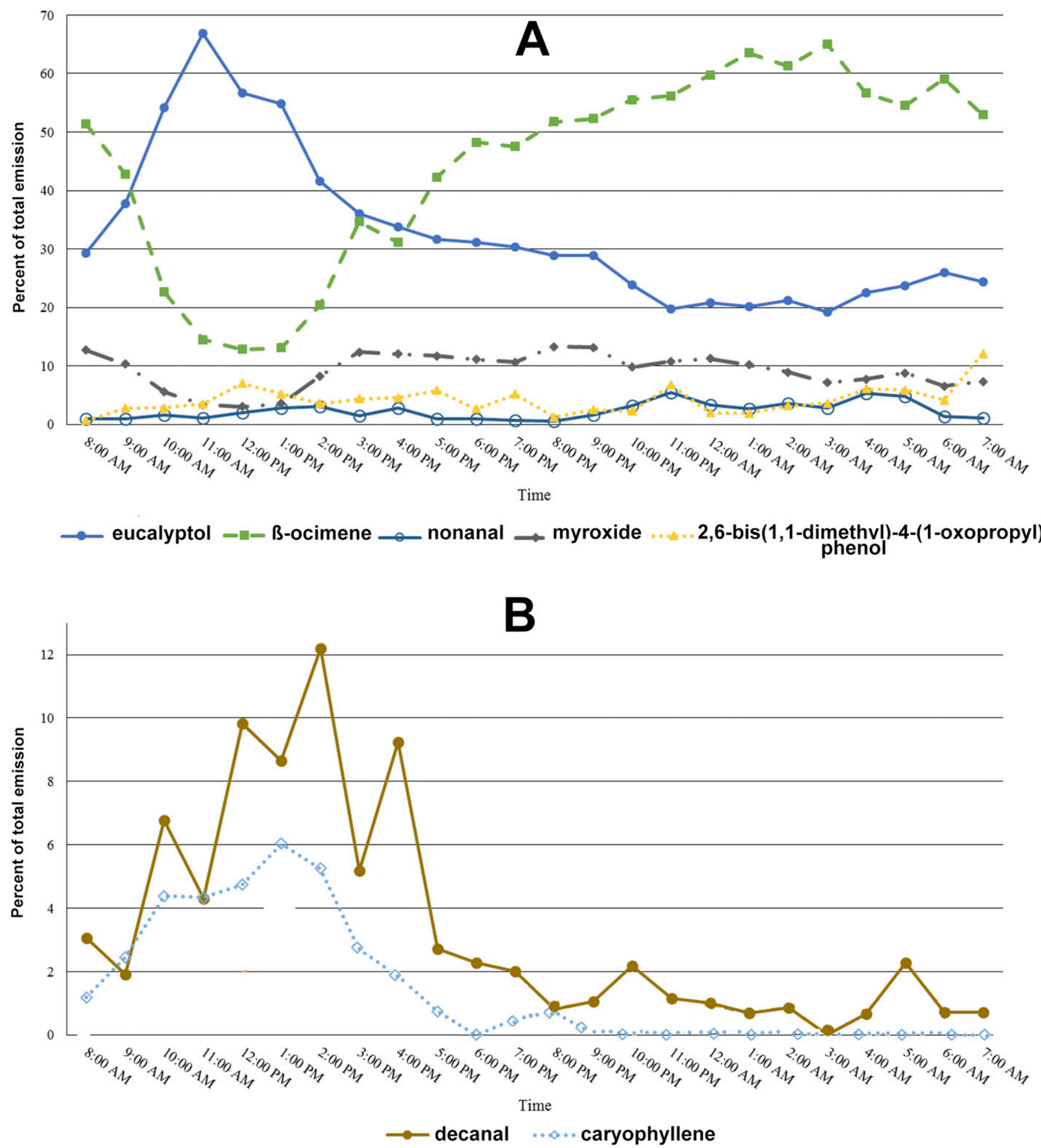

Fig. 3. Occurrence of volatile compounds emitted from Hippeastrum parodii flowers over a 24-h period. (A) Major and minor volatile compounds. Two additional minor volatiles are shown in a separate graph (B) for clarity. (B) Additional minor volatile compounds.

Hippeastrum parodii produced comparatively less scent than $H$. brasilianum. The difference was easily discernable by the human nose (as tested with all four authors). From 9:00 AM until 5:00 PM, H. parodii emissions were comparatively low with few high peak emissions (Fig. 4B). Scent emissions increased in the early evening (after 6:00 PM) with higher peaks and mostly higher troughs. This pattern lasted until 1:00 AM

HortScience Vol. 52(12) December 2017 when emissions began to decline. Excluding a large spike in emissions at 8:00 $\mathrm{AM}$, after 4:00 AM, scent compounds were emitted at levels similar to that found during daylight hours.

\section{Discussion}

The floral bouquets of $H$. brasilianum and $H$. parodii differ in the relative richness of
VOC composition (greater in $H$. parodii; Fig. 1; Table 1). Headspace of $H$. brasilianum is dominated by ( $Z$ )- $\beta$-ocimene (Fig. 1A; Table 1), whereas that of $H$. parodii is dominated by both $(Z)$ - $\beta$-ocimene and eucalyptol (Fig. 1B; Table 1). A previous report (Miyake et al., 1998) for the sphingophilous Crinum asiaticum L. (Amaryllidaceae) also found $\beta$-ocimene to be the greatest VOC emitted by the flowers $(44.6 \%)$, in addition 


\section{Hippeastrum brasilianum}

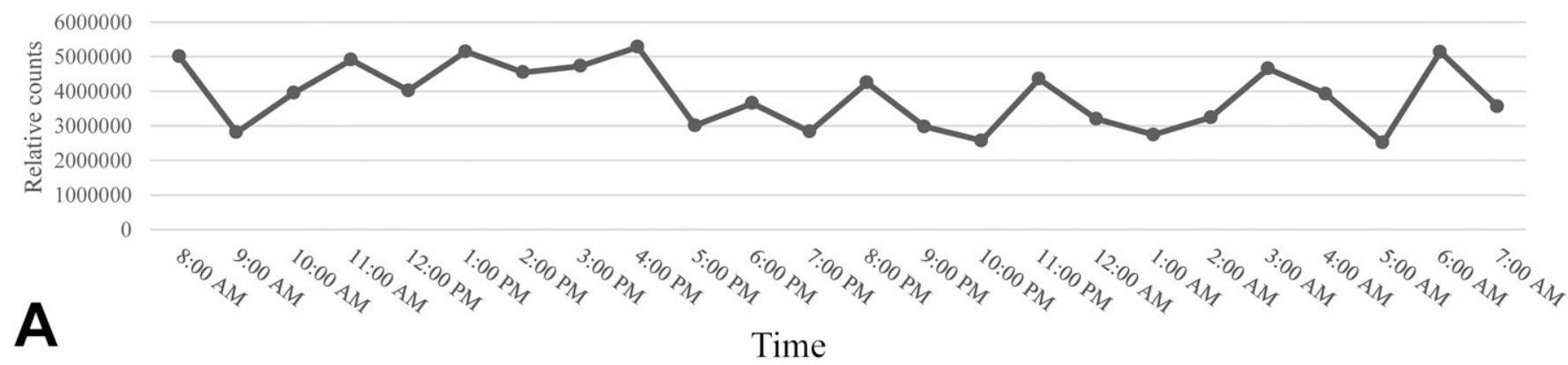

\section{H. parodii}

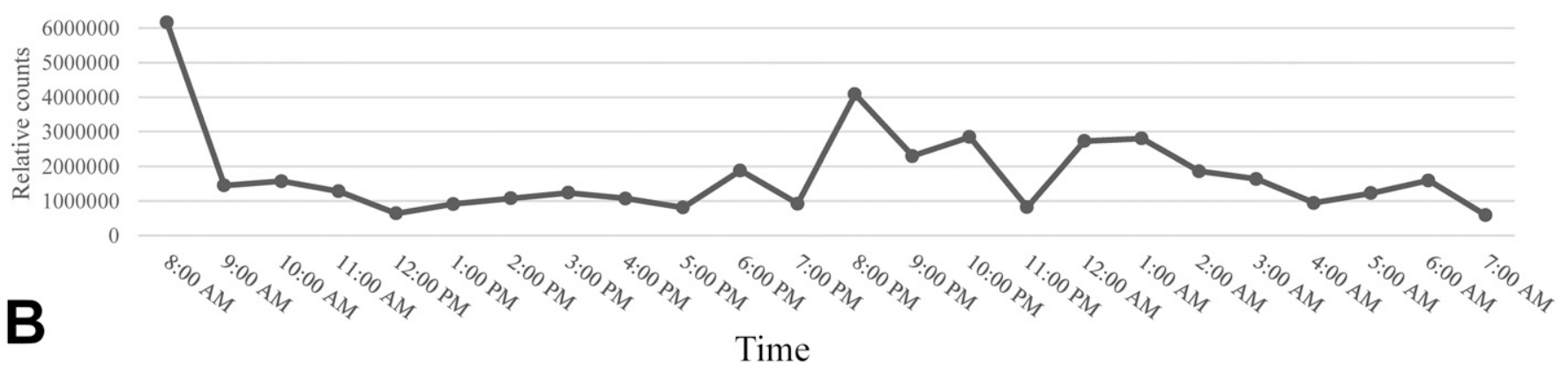

Fig. 4. Relative amount of floral scent emissions from two Hippeastrum spp. over a 24-h period. (A) Hippeastrum brasilianum. (B) Hippeastrum parodii.

to methyl benzoate $(12.6 \%)$, linalool $(8.4 \%)$, and nerolidol $(8 \%)$.

Both eucalyptol and $\beta$-ocimene are monoterpenes synthesized from the precursor geranyl pyrophosphate (Croteau et al., 1994; Dudareva and Pichersky, 2000; Peters and Croteau, 2003). Synthesis of eucalyptol at the expense of ocimene and vice versa may reflect an enzymatic/biochemical shift in conversion of geranyl pyrophosphate from one competitive pathway to another. Ocimene and myrcene emissions from snapdragon flowers were found to follow diurnal rhythms controlled by a circadian clock (Dudareva et al., 2003; Kolosova et al., 2001). Where snapdragon peak ocimene emission was between 11:00 AM and 6:00 PM, $H$. parodii's ocimene emission in our study peaked between 1:00 and 3:00 AM. Nevertheless, a circadian control mechanism in $H$. parodii is possible.

During the course of a day, floral scent can vary both in the intensity of emission and the makeup of compounds that result in the final scent (Balao et al., 2011; Dötterl et al., 2012; Effmert et al., 2005; Loughrin et al., 1990). Changes in temporal scent patterns can be a means to attract specific pollinators at different times of day or night to optimize pollination success (Dötterl et al., 2012; Effmert et al., 2005; Knudsen et al., 2006; Raguso et al., 2003). Both $H$. parodii and $H$. brasilianum had emission patterns that changed throughout a 24-h cycle (Fig. 4). Hippeastrum brasilianum is thought to be pollinated by moths because the flowers are white, long-tubed, and sweetly fragrant, fitting a sphingophilous syndrome (Dobson,
2006), though no documented visitation reports are available. The only anecdotal reports of insect visitation to $H$. parodii are two bumblebee and one butterfly species (M. Saviello, personal communication). Highvolatile emissions during daylight hours may indicate an alternative pollinator active during the day as these observations suggest.

Insect-pollinated flowers have much higher emission of VOCs than wind-pollinated flowers and a greater diversity of compounds in the scents that they produce (Farré-Armengol et al., 2015). Knudsen and Tollsten (1993) purport that flower adapted to hawkmoth (Sphingidae) pollination can be distinguished from those pollinated by noctuids (Noctuidae) by the presence of oxygenated sesquiterpenes in the VOC complement of sphingophilous species, but this observation has been refuted by later authors (Dobson, 2006). No sesquiterpenes were detected in $H$. brasilianum, but caryophyllene is a minor constituent of the VOCs of $H$. parodii (Table 1 ). Knudsen and Tollsten (1993) found that sphingophilous species were characterized by a major presence of farnesene, a VOC not present in either Hippeastrum species. Sphingophilous flowers also emit 1,8-cineole (i.e., eucalyptol), linalool, and nitrogen-containing VOCs when compared with flowers pollinated by noctuids (Knudsen and Tollsten, 1993). We detected linalool in $H$. brasilianum emissions, and eucalyptol was one of the two major peaks in $H$. parodii. We did not detect nitrogenous compounds in either species. Fatty acid derivatives, present in $H$. parodii, are associated with nocturnal settling moths (noctuids), rather than sphingids (Dobson, 2006).
Sphingid attraction to $H$. brasilianum may be suggested by the presence of linalool and methyl benzoate in the VOC emissions (Dobson, 2006), even though the species is not exclusively nocturnal (personal observation). Ultimately, it becomes difficult to predict the pollinators of plants by floral characteristics alone, including VOC emissions, in the absence of documented visitation (Dobson, 2006; Ollerton and Watts, 2000; Ramírez, 2003). The possibility that these species attract both diurnal and nocturnal lepidopteran visitors cannot be discounted.

VOCs reported for a fragrant complex hybrid of Hippeastrum (Liu and Yeh, 2015) and one of its parents were quite different from those reported here. They identified the emission constituents as cineole, 1,3,6-octatriene, $\beta$-linalool, 3-cyclohexene-1-methanol, and $\alpha$-farnesene. Only linalool was shared with one of the species we examined, $H$. brasilianum. This may suggest that introgression between species of the genus may result in novel VOC emissions.

The bat-pollinated $H$. calyptratum emits an even more complex bouquet (Bestmann et al., 1997): the oxygenated terpenes 1,8cineole $(18.3 \%)$, perillene $(13.1 \%)$, camphor $(2.9 \%)$, and linalool $(2.4 \%)$; the monoterpenes limonene $(27.5 \%), \gamma$-terpinene $(10.2 \%)$, $\beta$-myrcene $(8.7 \%)$, sabinene $(3.7 \%), \alpha$-pinene $(2.8 \%), \delta$-3-carene $(2.6 \%)$; the aliphatic 3 hexanone $(7.9 \%)$; and a few traces of other compounds. No sulfur-containing volatiles, implicated in many, but not all, bat-pollinated flowers (Bestmann et al., 1997; Dobson, 2006), were reported. 
Other than Hippeastrum and Crinum, floral emissions of Amaryllidaceae have only been studied in Narcissus (Dobson et al., 1997). Narcissus spp. pollinated by insects that include butterflies and moths were characterized by VOCs typical of moth-pollinated flowers, particularly indole combined with high amounts of esters. Species visited exclusively by non-lepidopterans, especially bees and flies, had fragrances lacking this combination of volatiles. Narcissus assoanus Dufour displayed both fragrance chemotypes, perhaps indicative to the documented patterns of interspecific hybridization in the genus (Marques et al., 2010, 2011).

Floral fragrance and breeding behavior in Hippeastrum. The hypothesis that floral fragrance is a recessive character in amaryllis (Meerow, 2000, 2009) is based on inheritance patterns we have observed over the course of several decades of breeding Hippeastrum. $\mathrm{F}_{1}$ hybrids of $H$. brasilianum and Hippeastrum papilio (nonfragrant) were uniformly without scent. Back-cross progeny ( $\mathrm{F}_{2}$ progeny were unavailable because of both self- and sibling incompatibility of the $F_{1}$ ) assort for fragrance. Others primary crosses between a fragrant and nonfragrant species also yield uniformly unscented progeny. In our experience, the $F_{1}$ of two fragrant species are uniformly scented.

In conclusion, volatile emissions of $H$. brasilianum and $H$. parodii are strongly suggestive of lepidopteran pollination. $H$. parodii in particular, with its biphasic alternation between eucalyptol and $(Z)$ - $\beta$-ocimene (Fig. 3A), may have more than one pollinator. We have recently obtained targeted (base of the perigone) floral transcriptomes of both $H$. brasilianum and $H$. papilio and hope to be able to use these genomic resources to understand the genetics of fragrance expression in amaryllis hybridization. Characterization of the fragrance volatiles of $H$. brasilianum in particular may assist in the identification of candidate genes involved in differential expression of this character. A wider distribution of floral fragrance in amaryllis hybrids is a desirable goal of breeding efforts in the genus.

\section{Literature Cited}

Altenburger, R. and P. Matile. 1988. Circadian rhythmicity of fragrance emission in flowers of Hoya carnosa R. Br. Planta 174:248-252.

Amrad, A., M. Moser, T. Mandel, M. de Vries, R.C. Schuurink, L. Freitas, and C. Kuhlemeier. 2016. Gain and loss of floral scent production through changes in structural genes during pollinator-mediated speciation. Curr. Biol. 26:3303-3312.

Araujo, A.C. and M. Sazima. 2003. The assemblage of flowers visited by hummingbirds in the "capões" of southern Pantanal, Mato Grosso do Sul, Brazil. Flora 198:427-435.

Aros, D., V. Gonzalez, R.K. Allemann, C.T. Muller, C. Rosati, and H.J. Rogers. 2012. Volatile emissions of scented Alstroemeria genotypes are dominated by terpenes, and a myrcene synthase gene is highly expressed in scented Alstroemeria flowers. J. Expt. Bot. 63:2739-2752.
Balao, F., J. Herrera, S. Talavera, and S. Dötterl. 2011. Spatial and temporal patterns of floral scent emission in Dianthus inoxianus and electroantennographic responses of its hawkmoth pollinator. Phytochemistry 72:601-609.

Bestmann, H.J., L. Winkler, and O. von Helversen. 1997. Headspace analysis of volatile flower scent constituents of bat-pollinated plants. Phytochemistry 46:1169-1172.

Chandler, S.F. and F. Brugliera. 2011. Genetic modification in floriculture. Biotechnol. Lett. 33:207-214

Croteau, R., W.R. Alonso, A.E. Koepp, and M.A. Johnson. 1994. Biosynthesis of monoterpenes: Partial purification, characterization, and mechanism of action of 1,8-cineole synthase. Arch. Biochem. Biophys. 309:184-192.

Delle-Vedove, R., N. Juillet, J.-M. Bessière, C Grison, N. Barthes, T. Paille, L. Dormont, and B. Schatz. 2011. Colour-scent associations in a tropical orchid: Three colours but two odours. Phytochemistry 72:735-742.

Dobson, H.E.M. 2006. Relationship between floral fragrance composition and type of pollinator, $p$. 147-198. In: N. Dudareva and E. Pichersky (eds.). Biology of floral scent. CRC Press, Boca Raton, FL.

Dobson, H.E.M., J. Arroyo, G. Bergström, and I. Groth. 1997. Interspecific variation in floral fragrances within the genus Narcissus (Amaryllidaceae). Biochem. Syst. Ecol. 25:685-706.

Dötterl, S., K. Jahrei, U.S. Jhumur, and A. Jürgens. 2012. Temporal variation of flower scent in Silene otitis (Caryophyllaceae): A species with a mixed pollination system. Bot. J. Linn. Soc. 169:447-460.

Dudareva, N., L. Cseke, V.M. Blanc, and E. Pichersky. 1996. Evolution of floral scent in Clarkia: Novel patterns of S-linalool synthase gene expression in the $C$. breweri flower. Plant Cell 8:1137-1148.

Dudareva, N., A. Klempien, J.K. Muhlemann, and I. Kaplan. 2013. Biosynthesis, function and metabolic engineering of plant volatile organic compounds. New Phytol. 198:16-32.

Dudareva, N., D. Martin, C.M. Kish, N. Kolosova, N. Gorenstein, J. Fäldt, B. Miller, and J. Bohlmann. 2003. (E)- $\beta$-ocimene and myrcene synthase genes of floral scent biosynthesis in snapdragon: Function and expression of three terpene synthase genes of a new terpene synthase subfamily. Plant Cell 15:1227-1241.

Dudareva, N., L.M. Murfitt, C.J. Mann, N. Gorenstein, N. Kolosova, C.M. Kish, C. Bonham, and K. Wood. 2000. Developmental regulation of methyl benzoate biosynthesis and emission in snapdragon flowers. Plant Cell 12:949961.

Dudareva, N. and F. Negre. 2005. Practical applications of research into the regulation of plant volatile emission. Curr. Opin. Plant Biol. 8:113-118.

Dudareva, N. and E. Pichersky. 2000. Biochemical and molecular genetic aspects of floral scents. Plant Physiol. 122:627-633.

Dudareva, N. and E. Pichersky. 2006. Floral scent metabolic pathways: Their regulation and evolution, p. 55-78. In: N. Dudareva and E. Pichersky (eds.). Biology of floral scent. CRC Press, Boca Raton, FL.

Effmert, U., J. Grobe, U.S.R. Rose, F. Ehrig, R. Kagi, and B. Piechulla. 2005. Volatile composition, emission pattern, and localization of floral scent emission in Mirabilis jalapa (Nyctaginaceae). Amer. J. Bot. 92:2-12.

Farré-Armengol, G., I. Filella, J. Llusià, and J. Peñuelas. 2015. Pollination mode determines floral scent. Biochem. Syst. Ecol. 61:44-53.
Fenske, M.P. and T. Imaizumi. 2016. Circadian rhythms in floral scent emission. Front. Plant Sci. 7:462.

Feulner, M., F. Schuhwerk, and S. Dotter. 2009. Floral scent analysis in Hieracium subgenus Pilosella and its taxonomical implications. Flora 204:495-505.

Freitas, L. and M. Sazima. 2006. Pollination biology in a tropical high-altitude grassland in Brazil: Interactions at the community level. Ann. Mo. Bot. Gard. 93:465-516.

Gershenzon, J., M.E. McConkey, and R.B. Croteau. 2000. Regulation of monoterpene accumulation in leaves of peppermint. Plant Physiol. 122:205213.

Guterman, I., M. Shalit, N. Menda, D. Piestun, M. Dafny-Yelin, G. Shalev, E. Bar, O. Davydov, M. Ovadis, M. Emanuel, and J. Wang. 2002. Rose scent genomics approach to discovering novel floral fragrance-related genes. Plant Cell 14:2325-2338.

Herrera, C.M. 1990. Daily patterns of pollinator activity, differential pollinating effectiveness, and floral resource availability, in a summerflowering Mediterranean shrub. Oikos 58:277288.

Jurgens, A., T. Witt, and G. Gottsberger. 2002 Flower scent composition in night-flowering Silene species (Caryophyllaceae). Biochem. Syst. Ecol. 30:383-397.

Knudsen, J.T., R. Eriksson, J. Gershenzon, and B Ståhl. 2006. Diversity and distribution of floral scent. Bot. Rev. 72:1-120.

Knudsen, J.T. and L. Tollsten. 1993. Trends in floral scent chemistry in pollination syndromes: Floral scent composition in moth-pollinated taxa. Bot. J. Linn. Soc. 113:263-284.

Knudsen, J.T., L. Tollsten, and L.G. Bergstrom. 1993. Floral scents: A checklist of volatile compounds isolated by head-space techniques. Phytochemistry 33:253-280.

Kolosova, N., N. Gorenstein, C.M. Kish, and N Dudareva. 2001. Regulation of circadian methyl benzoate emission in diurnally and nocturnally emitting plants. Plant Cell 13:2333-2347.

Li, S., L. Chen, Y. Xu, L. Wang, and L. Wang. 2012. Identification of floral fragrances in tree peony cultivars by gas chromatography-mass spectrometry. Scientia Hort. 142:158-165.

Liu, Q., G. Sun, S. Wang, Q. Lin, J. Zhang, and X. Li. 2014. Analysis of the variation in scent components of Hosta flowers by HS-SPME and GC-MS. Scientia Hort. 175:57-67.

Liu, M.-C. and D.-M. Yeh. 2015. 'T.S.S. No.1-Pink Pearl': A double-flowered and fragrant amaryllis cultivar. HortScience 50:1588-1590.

Loughrin, J.N., T.R. Hamilton-Kemp, R.A. Andersen, and D.F. Hildebrand. 1990. Volatiles from flowers of Nicotiana sylvestris, $N$. otophora and Malus $\times$ domestica: Headspace components and day/night changes in their relative concentrations. Phytochemistry 29:2473-2477.

Marques, I., G.N. Feliner, D. Draper Munt, M.A Martins-Loução, and J.F. Aguilar. 2010. Unraveling cryptic reticulate relationships and the origin of orphan hybrid disjunct populations in Narcissus. Evolution 64:23532368

Marques, I., G.N. Feliner, M.A. Martins-Loução, and J.F. Aguilar. 2011. Genome size and base composition variation in natural and experimental Narcissus (Amaryllidaceae) hybrids. Ann. Bot. 109:257-264.

Matile, P. and R. Altenburger. 1988. Rhythms of fragrance emission in flowers. Planta 174:242247. 
Meerow, A.W. 2000. Breeding amaryllis, p. 174 195. In: D.J. Callaway and M.B. Callaway (eds.). Breeding ornamental plants. Timber Press, Portland, OR.

Meerow, A.W. 2009. Tilting at windmills: 20 years of Hippeastrum breeding. Isr. J. Plant Sci. 57:303-313.

Miyake, T., R. Yamaoka, and T. Yahara. 1998. Floral scents of hawkmoth-pollinated flowers in Japan. J. Plant Res. 111:199-205.

Ollerton, J. and S. Watts. 2000. Phenotypic space and floral typology: Towards an objective assessment of pollination syndromes. Norske Vidensk.-Akad. I. Mat. Naturvid. Kl. Skrif., Ny Ser. 39:149-159.

Pare, P.W. and J.H. Tumlinson. 1997. De novo biosynthesis of volatiles induced by insect herbivory in cotton plants. Plant Physiol. 114:1161-1167.
Peters, R.J. and R.B. Croteau. 2003. Alternative termination chemistries utilized by monoterpene cyclases: Chimeric analysis of bornyl diphosphate, 1,8-cineole, and sabinene synthases. Arch. Biochem. Biophys. 417:203-211.

Raguso, R.A., R.A. Levin, S.E. Foose, M.W Holmberg, and L.A. McDade. 2003. Fragrance chemistry, nocturnal rhythms and pollination "syndromes" in Nicotiana. Phytochemistry 63:265-284

Ramírez, N. 2003. Floral specialization and pollination: A quantitative analysis and comparison of the Leppik and the Faegri and van der Pijl classification systems. Taxon 52:687712 .

Ramya, M., O.K. Kwon, H.R. An, P.M. Park, Y.S Baek, and P.H. Park. 2017. Floral scent: Regulation and role of MYB transcription factors. Phytochem. Lett. 19:114-120.
Sazima, I., S. Buzato, and M. Sazima. 1996. An assemblage of hummingbird-pollinated flowers in a montane forest in southeastern Brazil. Bot. Acta 109:149-160.

Steenhuisen, S.-L., R.A. Raguso, A. Jürgens, and S.D. Johnson. 2010. Variation in scent emission among floral parts and inflorescence developmental stages in beetle-pollinated Protea species (Proteaceae). S. Afr. J. Bot. 76:779-787.

Vainstein, A., E. Lewinsohn, E. Pichersky, and D. Weiss. 2001. Floral fragrance: New inroads into an old commodity. Plant Physiol. 127:1383-1389.

Verdonk, J.C., M.A. Haring, A.J. van Tunen, and R.C. Schuurink. 2005. ODORANT1 regulates fragrance biosynthesis in petunia flowers. Plant Cell 17:1612-1624.

Vogel, S. 1969. Chiropterophile in der neotropischen Flora. Neue Mitteil. III. Flora 158:289-323. 